\title{
Effect of clove oil treatment on the frozen storage Indian mackerel (Rastrelliger kanagurta) steaks
}

\author{
- Jitesh SOlanki ${ }^{1 *}$, PraKash PARMAR ${ }^{1}$, Hitesh PARMAR ${ }^{1}$, HitendRAKUMAR PARMAR $^{1}$, \\ VANRAJ CHAVDA ${ }^{1}$ AND ANIL KOTIYA ${ }^{2}$ \\ ${ }^{1}$ College of Fisheries (J.A.U.), VERAVAL (GUJARAT) INDIA \\ ${ }^{2}$ Fisheries Training and Research Centre (J.A.U.), MAHUVA (GUJARAT) INDIA \\ Email : jitesh_jeet@yahoo.com \\ *Author for Correspondence \\ Research chronicle : Received : 01.10.2016; Revised : 27.10.2016; Accepted : 28.11.2016
}

SUMMARY :

The antioxidant effect of clove on the frozen storage stability of fish steak from Indian mackerel (Rastrelliger kanagurta) was studied. Fresh mackerel as a raw material had moisture content 73.99 per cent, crude protein 18.16 per cent, crude fat 3.73 per cent and ash 1.71 per cent. The steaks from whole mackerel were treated with Clove oil $0.5,1.0$ and $1.5 \mathrm{ml}$ per lit. of distilled water for 5 minute. All samples were stored at $-18 \pm 2^{\circ} \mathrm{C}$ for the six months storage and experimental analysis. Based on the overall acceptability scores, $0.5 \mathrm{ml}$ clove oil treatment is found to better consumer acceptance than other samples during storage.

KEY WORDS : Clove oil, Mackerel, Rastrelliger kanagurta, Steak, Frozen storage

How to cite this paper : Solanki, Jitesh, Parmar, Prakash, Parmar, Hitesh, Parmar, Hitendrakumar, Chavda, Vanraj and Kotiya, Anil (2016). Effect of clove oil treatment on the frozen storage Indian mackerel (Rastrelliger kanagurta) steaks. Internat. J. Proc. \& Post Harvest Technol., 7 (2) : 269-273. DOI: 10.15740/HAS/IJPPHT/ 7.2/269-273. 